\title{
Difference Demonstration Method with Phantom and Film Viewing in Increasing Student Knowledge about the Physical Examination in Pregnant Women
}

\section{Anita Juniarti}

Postgraduate Student Faculty of Public Health, Universitas Indonesia, Depok, Indonesia

\section{Abstract}

Demonstration method and film viewing were methods used in the study of the physical examination of pregnant women. Based on recapitulation value lesson about the physical examination of pregnant women, $50 \%$ of the students got grade $C$ (65-67). The objective of the study was to examine the different of increasing of student knowledge between demonstration method with phantom and film viewing about examination physical to pregnant. This study used as an experiment with pre-test and

Corresponding Author:

Anita Juniarti

anita.juniarti@ui.ac.id

Received: 26 December 2018 Accepted: 23 February 2019 Published: 7 March 2019

Publishing services provided by Knowledge E

(c) Anita Juniarti. This article is distributed under the terms of the Creative Commons

Attribution License, which permits unrestricted use and redistribution provided that the original author and source are credited.

Selection and Peer-review under the responsibility of the $2 \mathrm{nd}$ International Meeting of Public Health 2016 Conference Committee. post-test designs. Population was 40 students, through purposive sampling with criteria selection such as student got grade C (65-67), 20 students. They were divided into two group, the first group was 10 students, as participant demonstration method with phantom treatment for 30 minutes. The second group was 10 students as participant film viewing treatment for 25 minutes 33 second. Each group got once treatment. Before got treatment, each group worked pre-test with 11 questions, after got treatment each group worked post-test with the same question like pre-test. Data analysis used univariate and test. The results showed a mean between demonstration method with phantom and film viewing almost equal with mean difference 0.6. Mean of difference knowledge with demonstration method with phantom 1.6 ( $p$-value $=0.000$ ) and film viewing $0.9(p$-value $=0.001)$. Demonstration method with phantom was better than film viewing to increase student knowledge about examination physical to pregnant women.

Keywords: Knowledge; student; phantom; film

\section{Introduction}

Obstetric complications handling is carried out through the early detection of complications in pregnant women. Early detection complication in pregnant women when the mother visited the health workers through a physical examination in pregnant women. 
body from head to toe was performed in pregnant women by standard operating procedures (Hidayati, 2010). Politeknik Kesehatan Bengkulu as a high education institution that prepares human health resources with good quality at vocational level was expected to provide health services in institutions and communities. In National Curriculum 2002, it described one of a subject was studied Midwifery Care I (Askeb I). A topic that was discussed the physical examination in pregnant women (Depkes RI 2008).

Based on the results of the final value of Askeb I, Subject learned about the physical examination of pregnant women. Almost $50 \%$ the students got grades $C$ (65-67), student obtained a grade B $47.5 \%(68-78)$ and only one student $(2.5 \%)$ got grade A (with 80), so that the low achievement illustrated the value of Askeb I. Physical examination of the pregnant mother was the basis midwifery competencies necessary for students midwifery. In the process of learning in Politeknik Kesehatan Bengkulu, it used learning method through practice and theory. Techniques were used include lectures, discussions, question and answer, and the role play. Demonstration method was the method used to show something processes of the workings of an object respectively to teach materials (Djamarah 2005). Demonstration method was one of a way that learning about the practice of physical examination in pregnant women. Physical examination for pregnant women used tools such as phantom, with the aim to allow students to apply the assigned material and practice the skills with practice on the model or illusion before to human (Sanaky 2009).

Phenomena happened in Poltekkes Bengkulu Prodi Kebidanan Curup; demonstration method tends to do with little time, while students could study with film viewing about physical examination for pregnant women. Also, it remains unknown how much influence the method of demonstration and film observing to increase student knowledge about the physical examination in pregnant women so that researchers interest in conducting research titled "Difference Demonstration Method with Phantom and Film Viewing in increasing student knowledge about the physical examination in pregnant women." The objective of the study was to examine different increasing student knowledge between demonstration method with phantom and film viewing about examination physical to pregnant.

\section{Methods}

This study used quasi-experiment with pre-test and post-test designs (Pratomo and Sudarti 2006). This study used two groups: the group demonstration method with phantom and the other group treated with the film viewing. Variables were used to explain problems in this study consisted of an intervening variable was demonstration 
method of the phantom (X1), film viewing $(X 2)$ and the dependent variable that student knowledge (Y). The population of the study was 20 students in Prodi Kebidanan Curup Poltekkes Kemenkes Bengkulu Semester III 40 students in 2011. The criteria of the participants in this study were students Prodi Kebidanan Curup Poltekkes Kemenkes Bengkulu Semester III got a grade of C (65-69) in Askeb I (20 people). On September 10,2010 , before starting this study, the researcher had done the validity and reliability test of the questionnaire to 15 students (participants) Semester III Prodi Midwifery Curup beyond the study participant.

TABLE 1: The results of the questionnaire validity test student knowledge about Physical Examination on Pregnant Women.

\begin{tabular}{|l|c|c|c|}
\hline No question & r count & r table & Status \\
\hline 1 & 0.6180 & 0.553 & Valid \\
\hline 2 & 0.0842 & 0.553 & No valid \\
\hline 3 & 0.6459 & 0.553 & Valid \\
\hline 4 & 0.0548 & 0.553 & No Valid \\
\hline 5 & 0.5995 & 0.553 & Valid \\
\hline 6 & 0.6101 & 0.553 & Valid \\
\hline 7 & 0.6557 & 0.553 & Valid \\
\hline 8 & 0.5669 & 0.553 & Valid \\
\hline 9 & 0.6199 & 0.553 & Valid \\
\hline 10 & 0.6557 & 0.553 & Valid \\
\hline 11 & 0.6180 & 0.553 & Valid \\
\hline 12 & 0.6084 & 0.553 & Valid \\
\hline 13 & 0.1110 & 0.553 & NoValid \\
\hline 14 & 0.5769 & 0.553 & Valid \\
\hline 15 & 0.0314 & 0.553 & NoValid \\
\hline Source: Primer Data (Be treated with SPSS for Windows version 15.0, 2010) \\
\hline
\end{tabular}

Based on Table 1, it showed 11 question items used in the questionnaire. On October 18,2010 , the researcher asked an agreement with a participant. Then participants were divided into two groups: the first group of 10 people, as a participant for treatment method with a phantom demonstration, then the second group of 10 people for treatment through film viewing of the physical examination in pregnant women.

The research process was Group I got demonstration method with a phantom. Group II got film viewing as the treatment in Poltekkes Bengkulu Prodi Kebidanan Curup. Before demonstration with phantom methods and film viewing, all participants give a briefing on procedures for these activities; then they did pre-test for 15 minutes with a questionnaire of 11 questions to measure student knowledge about the physical examination in pregnant women. After that, each group was treated by the purpose of research, either through demonstration method with phantom or film viewing of pregnant women 
physical examination for 25 minutes 33 seconds duration and once each treatment. Furthermore, post-test conducted for 15 minutes by using the same questionnaire with a pretest - data that were inserted into the data collection format after the data processing and analysis had been was done by univariate and bivariate analysis.

\section{Results}

\subsection{Univariate analysis}

The description of the category of the student knowledge level of physical examination in pregnant women before and after being treated through a demonstration with phantom methods and film viewing could be seen in the following table.

TABLE 2: Average Student Knowledge about Physical Examination of Pregnant Women Before got Demonstration Method with Phantom and Film Viewing.

Variables
Demonstration Method
Film Viewing

\begin{tabular}{|c|c|c|}
\hline $\mathbf{n}$ & Mean & Median \\
\hline 10 & 6.3 & 6 \\
\hline 10 & 6.4 & 6.5 \\
\hline
\end{tabular}

\begin{tabular}{|c|}
\hline SD \\
\hline 0.675 \\
\hline 0699 \\
\hline
\end{tabular}

\begin{tabular}{c} 
Minimum \\
\hline 5 \\
5 \\
\hline
\end{tabular}

Maximum
7
7

Table 2 showed that the mean value of the students about physical examination in pregnant women was almost equal to the difference of 0.1 .

TABLE 3: Average Student Knowledge about Physical Examination of Pregnant Women After got Demonstration Method with Phantom and Film Viewing.

Variables
Demonstration Method
Film Viewing

\begin{tabular}{|c|c|}
\hline $\mathbf{n}$ & Mean \\
\hline 10 & 7.9 \\
\hline 10 & 7.3 \\
\hline
\end{tabular}

\begin{tabular}{|c|}
\hline Median \\
\hline 7 \\
8 \\
\hline
\end{tabular}

\begin{tabular}{|c|}
\hline SD \\
\hline 0.568 \\
\hline 0.949 \\
\hline
\end{tabular}

\begin{tabular}{c|} 
Minimum \\
\hline 5 \\
5
\end{tabular}

\begin{tabular}{c} 
Maximum \\
7 \\
7 \\
\hline
\end{tabular}

According to Table 3, it was found that there were differences in mean improvement through demonstration method with phantom and film viewing, with a mean difference of 0.6 .

\subsection{Bivariate analysis}

Bivariate analysis was performed with t-test, classified into some categories with figures with a $95 \%$ confidence level.

Table 4 showed that demonstration method was better than film viewing in increasing knowledge of students. 
TABLE 4: Comparison average value pre-test and post-test student knowledge after got Demonstration Method and Film Viewing.

Variable
Demonstration Method
Film Viewing

\begin{tabular}{|c|}
\hline $\begin{array}{c}\text { Pre-test } \\
\text { Mean }\end{array}$ \\
\hline 6.3 \\
\hline 6.4 \\
\hline
\end{tabular}

\begin{tabular}{|c|}
\hline $\begin{array}{c}\text { Post-test } \\
\text { Mean }\end{array}$ \\
\hline 7.9 \\
7.3 \\
\hline
\end{tabular}

\begin{tabular}{|c|}
\hline $\begin{array}{c}\text { Mean } \\
\text { Difference }\end{array}$ \\
\hline 1.6 \\
0.9 \\
\hline
\end{tabular}

\begin{tabular}{|c|}
\hline $\mathbf{T}$ \\
\hline 7.23 \\
\hline 5.01 \\
\hline
\end{tabular}

\begin{tabular}{|l|}
\hline p value \\
0.000 \\
0.001
\end{tabular}

\section{Discussions}

Comparison of the average value of student knowledge before and after being treated through demonstration method with a phantom method and film viewing showed that there were differences between the mean before and after was being addressed, namely in the form of an increase in the average number of students essential knowledge. It was showed from the mean difference, an increased understanding by demonstration method with phantom 1.6 while through film viewing 0.9 , it showed that a demonstration method with phantom was better than movie viewing in increasiing knowledge of the student about examination physical to pregnant women.

Physical examination of pregnant women was conducted on the body from head to toe by standard operating procedures (Hidayati 2010). Demonstration method was a method of teaching by way of demonstrating goods, events, rules, and the order to do an activity (Syah 2005). In a demonstration of the methods, it was usually applied by using assistive devices such as small objects, images, laboratory equipment devices, including phantom. Demonstration method with phantom had some advantages, including the following: a) through the process of demonstration, the occurrence of verbal can be avoided, because the students were directed to the lesson material; b) the learning process would be more interesting, because students not only heard but also saw events that happened; c) by way of directly observing, the students would have the opportunity to compare between theory and reality. Students would be convinced of the truth of learning materials (Hidayati2010).

Phantom was medium that could be objected for mocking three dimensional of some real objects that were too big, too far, too small, too expensive, too little, or too complicated to be brought into the classroom (Sudjana and Riva 2002). Phantom had some benefits including the following: a) natural learning process in the classroom; b) improve the efficiency of the learning process; $c$ ) maintain the relevance of the subject matter with the aim of learning; d) asswast in the process of learning. Based on Kamus Besar Bahasa Indonesia (2005) film viewing was: a) movie, thinner membranes made from celluloid to a negative image that would later become a portrait or a positive picture that would play in the cinema; b) the film was a story (story) live image. According to Hasan (2010), the 
strengths of film media were: a) leaving a message that could be received more evenly by the students; b) very careful to explain a process; c) overcoming the limitations of space and time; d) better realistic, repeatable and terminated in accordance with the requirements; e) leaving a deep impression, which could affect students' attitudes.

The results of this study consistently was in line with research conducted by Pulungan (2007), showing that there was a significant difference between knowledge before (12.60) and after (1962) the extension services with the mean difference of 7.02 ( $p$-value $<0.05$ ). This was supported by the opinion of Amalia (2010) that stated health education with the methods of demonstrations might affect the knowledge of knowing it at early adulthood when it compared with the airing of the film, with the results of a participant of 72 people. The result of T-test on knowledge was 2.750 with significant value 0.008 ; T-test results on attitudes was 0.228 with significant amount 0.820 and the T-test results on the behavior was 2.057 with significant value 0.043 .

The results of this study were consistent with the results of research Partiyah (2010) stated that 16 students (88.9\%) felt an increase in knowledge and only $1(5.56 \%)$ student who did not have the influence after teachers used instructional media in the form of screening. The results showed that in the implementation of the teaching and learning of Islamic religious education, teachers with the use of instructional media worked out well, indicated by the students that were more interested in following the lesson. The students got more active, more easily to understood, motivated, and didn't feel bored. Many factors that supported the lesson included mastery of the material with which motivated the child's condition, accuracy in choosing the media, while the limiting factor was the lack of enough attention from parents and media limitations that were provided by the school.

\section{Conclusions}

Demonstration method with phantom was better to increase the knowledge of students about physical examination in pregnant women when compared with the film viewing. The suggestions in this study were: a) Educational institutions: preferably in the practice of the learning process, the educational institutions, increasing the number of small groups in the classroom while doing a demonstration with a phantom method. It aims to improve the understanding of students knowledge; b) For further research, other researchers can develop this study by assessing the learning styles of students, which affects students' experience in the learning process 


\section{Acknowledgments}

The author presents her sincere appreciation for:

1. Mr. Dr. Besral, S.K.M., M.Sc. as academic counselors that gave guidance about study

2. Mrs. Dr. Dra. Dewi Susana., M.K.M who gave suggestions and corrections in this study

3. Mrs. Hj. Elly Nur, SKP., M.Kes nd Mrs. Hj. Sri Sumiati, AB, Spd., M.Kes, in Poltekkes Kemenkes Bengkulu as a lecture to provide guidance and directions that become substantial completion of this study

4. Miss. Rizka Maulida, M.Hsc, who gave contribution in this completion of this study

5. All participants have agreed to become respondent to end this study

\section{References}

[1] Amalia, Amirul. 2010. Pengaruh Pendidikan Kesehatan terhadap Pengotahuan, Sikap dan Perilaku Sadaripada Wanita Dewasa Awal d Desa Sumberwono Kecamatan Bangsal Tahun 2010. Teswas. Fakultas Kesehatan Masyarakat. Universitas Sebelas Maret. Jawa Tengah.

[2] Departemen Kesehatan RI. 2008. Swastem Kesehatan Nasional: Bentuk dan Cara Penyelenggaraan Pembangunan Kesehatan. Jakarta: Depkes RI.

[3] Djamarah, Syaiful. 2008. Strategi Belajar Mengajar. Jakarta: PT. Rineka Cipta.

[4] Hasan, Latief. 2010. Klasifikasi Media Pembelajaran.Jakarta: PT. Rineka Cipta.

[5] Hidayati, Ratna. 2010. Asuhan Keperawatan pada Kehamilan Fwasiologwas dan Patologwas. Jakarta: PT Rineka Cipta

[6] Kamus Besar Bahasa Indonesia. 2005. Jakarta: EGC

[7] Kementerian Kesehatan RI. 2008. Panduan Pelaksanaan Strategi MPS dan Child Siurvival. Jakarta: EGC

[8] Partiyah. 2010. Efektifitas Penggunaan Media Pembelajaran Pendidikan Agama Waslam di SDN 2 Ngemplak Kabupaten Sleman Tahun 2010. Skripsi. Universitas Waslam Indonesia. Yogyakarta

[9] Pratomo and Sudarti.2006. Pedoman Pembuatan Usulan Penelitian Bidang Kesehatan Masyarakat dan KB. Jakarta. PMU Pengembangan FKM di Indonesia. Departemen Pendidikan dan Kebudayaan RI. 
[10] Pulungan. 2007. Efeketifitas Penyuluhan Sadari Melalui Penayangan Film Terhadap Peningkatan Pengotahuan Remaja Tentang Sadari di SMA Negeri I Kecamatan Sidamanik Kabupaten Simalungun. Skripsi. Fakultas Keperawatan: Universitas Sumatera Utara

[11] Sanaky, H.2009. Media Pembelajaran. Yogyakarta: Safiria Insania Press

[12] Sudjana, Nana and Rivai, Ahmad. 2002. Media Pembelajaran Penggunaan dan Pembuatannya. Bandung: Sinar Baru.

[13] Syah, Muhibin. 2005. Psikologi Pendidikan suatu Pendekatan Baru. Bandung: Remaja Rosda Karya. 